\title{
KEPERCAYAAN RELIGIUS-MAGIS MASYARAKAT PEDESAAN KECAMATAN JEROWARU LOMBOK TIMUR-NTB (Studi Terhadap Budaya Asli Masyarakat Yang Masih Eksis)
}

\author{
SIPA SASMANDA
}

Pendidikan Sejarah, Universitas Muhammadiyah Mataram, Sipasasmanda@yahoo.co.id

INFO ARTIKEL
RiwayatArtikel:
Diterima: 03-11-2016
Disetujui: 02-12-2016

\section{Kata Kunci:}

1. Kepercayaan religius-magis,

2. Masyarakat pedesaan.

\begin{abstract}
ABSTRAK
Abstrak:

Agama dan kepercayaan merupakan unsur dari kebudayaan maka dalam hal ini akan dikaji dengan menggunakan pendekatan budaya. Untuk lebih memahami kebudayaan Indonesia yang asli terutama dalam hal kepercayaan tentu kita harus melihat perjalanannnya dari perkambangan waktu yang ada atau perkembangan sejarahnya. Tulisan ini menkaji tentang kepercayaan religius-magis masyarakat pedesaan kecamatan Jerowaru Lombok Timur-NTB. Metode penelitian ini yaitu kualitatif. Penentuan subjek penelitian dilakukan secara purposif sampling. Pengumpulan data dilakukan dengan cara pengamatan, wawancara, dan dokumnetasi.pemeriksanaan keabsahan data menggunakan metode triangulasi. Hasil menunjukkan bahwa kepercayaan religius-magis masyarakat pedesaan kecamatan Jerowaru Lombok Timur-NTB masih terikat oleh kepercayaan religuis-magis yang pernah menjadi kepercayaan nenek moyang mereka. Beberapa unsur kepercayaan religius-magis yang masih di lestarikan oleh masyarakat seperti bebubus, kekuatan supranatural dari ketobok dan kemalik, percaya pada mantra-mantra yang dapat mengakibatkan kekebalan tubuh, percaya pada pelet, senggeger serta sengasih-asih dan lain sebagainya.

Religion and beliefs are an element of culture then in this case will be studied using a cultural approach. To better understand indigenous Indonesian culture, especially in the case of belief, we must see the journey from the existing time mining or historical development. This paper examines the religious-magical belief of the rural community of Jerowaru sub-district, East Lombok-NTB. The method of this research is qualitative. Determination of research subjects conducted by purposive sampling. Data collection is done by observation, interview, and dokumnetasi.per checking data validity using triangulation method. The results show that the religious-magical belief of the rural community of Jerowaru sub-district of East Lombok-NTB is still bound by the religious-magical beliefs that were once the beliefs of their ancestors. Some elements of religious-magical beliefs that are still preserved by society such as bebubus, supernatural powers of ketobok and kemalik, believe in spells that can lead to immunity, believe in pellets, senggeger and merciful-asih and so forth.
\end{abstract}

\section{A. LATAR BELAKANG}

Salah satu unsur kebudayaan yang penting dari tujuh unsur kebudayaan sebagaimana dikatakan antropolog C. Kluckhohn (Soerjono Soekanto, 1982) adalah religi (sistem kepercayaan). Dengan demikian maka sistem kepercayaan ini dapat kita lihat dalam konteks kebudayaan baik penerapan maupun fungsinya dalam kehidupan masyarakat. Demikian pentingnya agama sebagai unsur yang menentukan jalannya kehidupan masyarakat, Christopher Dawson (Soejatmoko dkk, 1995) mengatakan bahwa "agama adalah kunci sejarah. Kita tidak dapat memahami bentuk dalam diri satu masyarakat jika kita tidak memahami agama. Kita tidak dapat memahami hasil kebudayaannya jika kita tidak memahami kepercayaan agama yang ada di sekitar mereka. Dalam semua zaman, hasil karya kreatif pertama dari suatu kebudayaan muncul dari inspirasi agama dan di abdikan pada tujuan keagamaan. Adapun agama yang di maksud di sini adalah berupa kepercayaan baik di sebut agama ukhrowi maupun duniawi, dan termasuk di dalamnya mulai dari animisme dan dinamisme, Hindu, Islam dan lain sebagainya.

Karena agama (kepercayaan) merupakan salah satu unsur dari kebudayaan maka dalam hal ini agama 
yang di maksud akan di kaji dengan menggunakan pendekatan budaya. Untuk lebih memahami kebudayaan Indonesia yang asli terutama dalam hal kepercayaan tentu kita harus melihat perjalanannnya dari perkambangan waktu yang ada atau perkembangan sejarahnya.

Kepercayaan masyarakat Indonesia secara umum dalam perjalanan sejarahnya, seperti kebudayaankebudayaan primitif lainnya dalam sejarah, bangsa Indonesia sebelum datang kebudayaan India mempunyai kepercayaan kepada roh-roh atau tenaga-tenaga yang gaib meresapi seluruh kehidupan, baik kehidupan manusia perorangan maupun kehidupan masyarakat secara keseluruhan. Pikiran dan perbuatan tertuju bagaimana mendapat bantuan dari roh-roh yang baik-baik dan bagaimana menjauhkan pengaruh roh-roh yang mengganggu atau menghalangi. Dan untuk mencapai maksud itu ada bermacam-macam ritus, mantera, larangan dan suruhan yang memenuhi kehidupan dalam masyarakat yang bersahaja itu (Takdir Alisjahbana, 1988:3).

Dalam hubungannya dengan masyarakat terpelajar dan kepemimpinan, bahwa ilmu yang tertinggi ialah ilmu tentang roh-roh dan tenaga-tenaga yang gaib itu, yang berhubungan dengan proses dan ketertiban kosmos. Demikian pulalah orang yang termulia, terkuasa dan terpelajar dalam masyarakat itu ialah orang-orang yang mengetahui tentang roh-roh dan tenaga-tenaga yang gaib itu dalam hubungan proses dan ketertiban kosmos dan oleh pengetahuannya itu dapat mempengaruhinya untuk kepentingan manusia (Alisyahbana, 1988:4)

Menurut Takdir Alisyahbana, 1988) bahwa kbudayaan Indonesia asli berupa roh-roh dan tenaga gaib yang masih kabur bentuk dan fungsinya, dalam kebudayaan India telah berupa dewa-dewa yang lebih nyata pribadinya dan sifat-sifatnya sebagai lambang tenaga-tenaga alam, yang mempunyai hierarki dan fungsi yang tentu dalam proses kosmos maupun dalam kehidupan manusia. Roh-roh dan tenaga yang gaib dari kepercayaan bangsa Indonesia, bertemu dan dalam banyak hal terlebur dalam sistem dewa-dewa dan tenaga-tenaga sakti kepercayaan Hindu, yang telah lebih sempurna dipikirkan dan tersusun dari kepercayaan kebudayaan asli Indonesia.
Setelah kedatangan Islam, seperti kebudayaan Indonesia asli dan Hindu, kebudayaan Islam itupun berpusat pada kepercayaan kepada tenaga yang gaib, yang dalam kepercayaan Islam dinamakan Allah. Tetapi berbeda dengan animism dan dinamisma kepercayaan kebudayaan Indonesia asli dan berbeda dengan hierarki dewa-dewa dan imanentisma kebudayaan India, dalam kepercayaan Islam ada suatu jarak yang besar antara manusia dan Allah (Takdir Alisyahbana, 1988:12).

Kedatangan bangsa Barat ke Indonesia mulai dari abad ke-15 serta merta juga ikut mempengaruhi intelektual masyarakat terutama dalam hal penggunaan akal dalam menjalankan kehidupan sehari-hari, walaupun hal ini sudah di mulai setelah kedatangan islam, namun yang terakhir di sebutkan lebih mengarah pada hal-hal yang materialistis. Apa yang di bawa masyarakat Barat tidak lepas dari apa yang di katakana Aguste Comte (Ritzer \& Goodman, 2011; Bernard Rahoo, 2006) sebagai tahap positivisme yaitu lebih mengarah pada kebebasan akal untuk berpikir bahkan memikirkan tentang tuhan, hal ini juga mempengaruhi masyarakat Indonesia dalam hal kebudayaan yang di dalamnya juga terdapat kepercayaan masyarakat.

Berdasarkan keterangan di atas terkait dengan kepercayaan masyarakat dalam perjalanan sejarahnya secara umum memiliki tingkat perkembangan yang berbeda antara daerah, pulau dan tempat yang berbeda, bahkan dalam satu kawasan yang sama menunjukkan konten kepercayaan yang berbeda dalam waktu yang sama. Pengaruh kebudayaan India, Islam dan Modern memang pada kenyataannya melahirkan perkembangan kebudayaan yang berbeda, bisa berupa dan lebih condong di pengaruhi semua unsur kebudayaan, kepercayaan asli dan hindu serta sedikit islam seperti yang dapat kita lihat pada masyarakat Bayan Lombok Timur-NTB, atau sebaliknya lebih dominan kepercayaan masyarakat di pengaruhi kebudayaan asli Indonesia serta kepercayaan Islam seperti dapat kita saksikan pada masyarakat bagian selatan Lombok timur dan Lombok Tengah, lebih husus lagi di Kecamatan Jerowaru.

Walaupun dalam sejarah kebudayaan Indonesia terutama dalam hal kepercayaan telah di pengaruhi oleh berbagai unsur budaya, namun bagaimana pun unsur 
budaya asli terutama di daerah pedesaan walaupun sudah di pengaruhi kebudayaan yang berbeda dari aslinya namun akan tetap mewarisi kebudayaan aslinya, atau paling tidak memadukannya. Hal ini sejalan dengan apa yang di katakan Sutan Takdir Alisyahbana (Budiwanti: 2009) mengatakan bahwa adat-istiadat yang berlaku pada masyarakat berakar pada budaya yang dikembangkan oleh nenek moyang secara berkelanjutan bahkan tidak berkesudahan. Berdasarkan apa yang dikatakan Ali Syahbana diatas sekurang-kurangnya walaupun dengan adanya perkembangan ilmu pengetahuan yang kelihatannya memarjinalisasi sendi-sendi budaya terdahulu pada masyarakat, dengan pengamatan yang cermat pada masyarakat yang walaupun sudah terkontaminasi dengan budaya baru tersebut justru masih menyisakan kebajikan-kebajikan masa lalu yang terus di lestarikan keberadaannya. Sehingga dapat dikatakan bahwa kepercayaan terhadap agama, dilestarikan juga budaya-budaya masa lampau sekaligus juga menerima pengaruh moderinisasi.

\section{B. METODE PENELITIAN}

Metode penelitian ini menggunakan desain penelitian kualitatif. Penentuan subjek penelitian dilakukan secara purposif yaitu di masyarakat bagian selatan Lombok Timur dan Lombok Tengah, lebih khusus lagi di Kecamatan Jerowaru. Pengumpulan data dilakukan dengan cara pengamatan, wawancara mendalam, dan dokumnetasi. Pemeriksanaan keabsahan data menggunakan metode triangulasi. Selanjutnya data dianalisis untuk memberikan makna terhadap data yang telah dikumuplkan dan menarik kesimpulan.

\section{HASIL DAN PEMBAHASAN}

\section{Gambaran Umum Kepercayaan Masyarakat}

Kecamatan Jerowaru merupakan kecamatan yang paling selatan di Kabupaten Lombok Timur. Kecamatan yang selalu di landa kekurangan air ini di balik memiliki rasa kolektivitas yang cukup tinggi, sejauh ini masyarakatnya sangat telaten bekerja terutama sebagai petani. Karena sedikit sekali penduduknya yang berprofesi sebagai guru, pagawai atau pedagang misalnya, walaupun akhir-akhir ini menunjukkan kemajuan. Di bandingkan dengan kecamatan-kecamatan yang lain di Lombok Timur, Kecamatan jerowaru dalam bidang pendidikan masih terbelakang hal ini terbukti dari banyaknya pernikahan usia dini, dan hal ini banyak di kaji oleh para peneliti dari STKIP Hamzanwadi Selong,UNRAM dan lain sebagainya, dan di katakana bahwa inilah diantara salah satu penyebab dari banyaknya siswa yang putus sekolah dan sedikit sekali yang melanjutkan sampai ke perguruan tinggi. Bukan hanya itu kecamatan ini juga terkenal karena banyaknya terjadi kawin cerai, sehingga sering menjadi sampel untuk penelitian masalah kawin cerai di Lombok Timur.

Namun seperti dikatakan di atas bahwa masyarakat kecamatan Jerowaru terutama di pedesaannya diwarnai oleh kolektivitas yang masih tinggi, ini di sebabkan oleh adanya mata pencaharian yang hampir homogen, walaupun saat ini sudah menunjukkan adanya spesialisasi walaupun dalam tataran yang masih bisa dikatakan sangat kecil bila di bandingkan dengan presentasi masyarakat yang mata pencahariannya sebagai petani. Unsur homogenitas inilah yang sekaligus juga mengakibatkan adanya perasaan kolektivitas yang tinggi, sekaligus merupakan salah satu ciri dari masyarakat desa di manapun.

Adanya kolektivitas yang tinggi pada masyarakat pedesaan di kecamatan Jerowaru sekaligus juga menyebabkan kebudayaan masyarakat yang berasal dari nenek moyang mereka dapat terus menerus di pertahankan, terutama sekali dalam hal kepercayaan ini. Walaupun pada dasarnya saat ini sudah mulai berkurang dan hanya di lakukan oleh generasi tuanya saja dan ada beberapa ritual dan kepercayaan yang masih di lakukan dan di percaya oleh generasi mudanya, seperti bebubus dan lain sebagainya.

Pada dasarnya masyarakat pedesaan di Kecamatan Jerowaru tercatat beragama Islam yang salah satu ajarannya adalah melarang pemeluknya percaya pada benda-benda memiliki kekuatan gaib, atau percaya pada bantuan jin dan roh-roh seperti yang di percaya oleh masyarakat, meskipun dalam Islam juga terdapat kepercayaan pada yang gaib namun bukan seperti apa yang di percayakan oleh masyarakat seperti yang di jelaskan di atas yang di maksudkan. Apa yang di sebutkan 
di atas sesungguhnya bagi ajaran Islam adalah sesuatu tahayyul dan di larang dalam agama ini. Namun kembali pada apa yang di katakana di atas bahwa kepercayaan merupakan salah satu unsur budaya yang paling sulit atau paling tidak mudah untuk berubah, paling tidak kalaupun berubah kemungkinan besar akan terjadi akulturasi.

Kepercayaan kepada Allah oleh masyarakat pedesaan kecamatan Jerowaru karena menganut agama Islam tidak serta merta meninggalkan kepercayaan nenek moyang mereka akan kepaercayaan bahwa benda-benda seperti padi, dan binatang seperti tikus, babi, ulat, dan lain sebagainya memiliki kekuatan supranatural yang mengelilinginya, belum lagi kepercayaan masyarakat pada tempat-tempat yang dianggap keramat dan harus di lakukan sesaji. Kekuatan-kekuatan supranatural yang di milki oleh benda-benda, binatang-binatang serta tempattempat keramat tadi diasosiasikan sebagai jin oleh masyarakat yang dalam ajaran islam memang ada, sehingga masyarakat memandangnya hal ini bertentangan dengan ajaran islam, yang tidak benar bagi mereka adalah mempercayakannya sebagai kekuatan tertinggi, namun mereka juga mampu merubah sesuatu yang ada sehingga masyarakat harus mematuhinya atau melawannya.

\section{Beberapa Kepercayaan Religius-magis yang Masih Eksis}

Pada bagian ini kita akan coba menjelaskan serta mengklasifikasi beberapa kepercayaan religius-magis masyarakat pedesaan Kecamatan Jerowaru berdasarkan klasifikasi benda, binatang, tempat dan lain sebagainya. Karenanya untuk memperjelas maka kita akan membahas satu persatu diantara beberapa macam dan jenis kepercayaan religius-magis dari masyarakat bersangkutan.

\section{a. Dalam Bidang Pertanian}

Seperti sudah di jelaskan di atas bahwa pada umumnya pertanian merupakan pekerjaan yang mendominasi masyarakatnya, namun hal ini tidak sampai di situ saja, karena ada satu hal menarik yang perlu kita tahu pada kebudayaan masyarakat ini dalam hal pertanian ini. Mulai dari penentuan tanggal, dan hari yang bagus untuk menanam sampai pada kepercayaan dengan mantra-manta oleh orang yang ahli ketika hama menyerang tanaman sampai saat ini terus di percaya dan masih di lestarikan kepercayaan tersebut.
Langkah pertama yang biasanya diambil adalah menanyakan hari-hari yang bagus untuk penyemaian padi, hal ini bisa di tanyakan pada orang yang dianggap memiliki kekuatan spiritual yang bagus, dan di kecamatan Jerowaru kita tidak jarang akan bisa menemukan orang yang katanya mampu menunjukkan hari-hari yang bagus untu menanam padi. Selain itu masyarakat juga percaya pada kekuatan mantra yang di buat oleh ahli spiritual yang di tiupkan lewat selembar daun sirih yang di campur dengan kapur dan buah pinang yang di namakan dengan sembek untuk mengantisipasi hama dan penyakit atau gangguan jin pada tanaman padi, dan biasanya sembek ini di ganting di tengah-tengah sawah dengan sebatang ranting bambu.

\section{b. Benda-benda dan Binatang}

Beberapa binatang yang dapat merusak tanaman padi atau tanaman lainnya seperti ulat, tikus, dan babi di percayakan memiliki kekuatan, karena seperti yang di percayai masyarakat binatang tersebut di miliki oleh jin, karena itu mereka tidak berani menyumpahnya ketika merusak tanaman. hal ini bukan berarti mereka tidak berani membasminya melainkan mereka hanya takut untuk menyumpahnya, mereka meyakini kalau di sumpah maka yang empunya bakal marah. Kepercayaan seperti ini saat ini sudah mulai luntur namun masih ada sebagian masyarakat yang mempercayainya.

Tikus yang merusak tanaman padi di rumah biasanya oleh sebagian masyarakat di percaya mengerti jika mereka menyumpahnya dan akan merusak lebih parah lagi, sehingga kadang-kadang jika mereka melihat padinya yang berserakan mereka akan mengatakan "dende dendek sedak pare" yang artinya mereka bilang sama tikus tersebut untu tidak merusak padinya. Sebutan dende oleh masyarakat di Lombok adalah bahasa yang sangat bagus untuk memanggil anaknya sendiri maupun orang lain, yang pada dasarnya untuk penyebutan manusia.

Kucing juga dianggap memiliki balak. Hal ini berlaku misalnya ketika di tabrak, dan yang menabrak tersebut tidak mengangkatnya dan serta menguburkannya maka oleh masyarakat di percayai suatu saat dalam perjalanan sang pengendara tersebut akan mendapatkan bahaya. Penguburannnya juga tidak sembarangan, melainkan harus di bungkus menggunakan pakaian yang 
digunakan oleh orang yang menabrak tadi, bahkan lebih bagus lagi jika di bungkus dengan kain putih sebelum di masukkan dalam tanah.

\section{c. Pembuatan Bangunan}

Salah satu kepercayaan masyarakat sampai saat ini yang bertendensi kearah religius-magis dalam hal ini adalah saat pembangunan rumah misalnya. Masyarakat percaya bahwa harus di yakinkan bahwa di bawah pondasi tempat pembuatan rumah tersebut tidak ada batu besar. Karena batu besar dianggap sebagai tempat jin, dan jika mereka membuat rumah di atasnya maka di hawatirkan suatu saat mahluk gaib yang menghuni batu besar tersebut akan mengganggu pemilik rumah. Bukan hanya itu jika secara kasat mata batu besar tersebut tidak dapat di lihat maka mereka menggunakan tenaga ahli paranormal untuk memastikan bahwa tempat di mana akan di bangun rumah tersebut steril dari pengaruh jin dan mahluk gaib lainnya.

Begitu juga saat mereka akan membuat sumur, masyarakat akan menanyakan kepada sang ahli spiritual apakah tempat tersebut cocok untuk pembuatan sumur. Mereka percaya dengan kemampuan spiritual yang di miliki oleh ahlinya mampu menembus air yang ada di dalam tanah tersebut. Namun sebelum sang paranormal memastikan apakah tempat tersebut mengandung air yang banyak atau tidak sama sekali mereka membutuhkan waktu satu atau dua malam untuk mengkaji mimpinya. Jika hasil mimpinya mengisyaratkan ada maka dia akan menemui sang pemilik untuk memberitahukannya. Proses meditasi lewat mimpi ini disebut sebagai betangi.

\section{d. Kemalik dan Ketobok}

Kemalik dan ketobok memiliki objek yang dapat di lihat, baik berupa bangunan maupun hanya berupa benda. Antara kemalik dan ketobok ini memiliki perbedaan yang dapat kita pisahkan. Kemalik sering berupa batu besar, pohon besar dan kadang-kadang sebuah tempat yang kelihatan biasa-biasa namun di yakini oleh masyarakat di huni oleh banyak mahluk halus. Mahluk halusnya di yakini bisa berupa jin ular, jin kera, jin yang tua, dan lain sebagainya yang menguasai tempat tersebut. Anak-anak ataupun orang dewasa dilarang untuk bermain di tempat tersebut kalau tidak memiliki mantra yang bisa mengalahkan jin tersebut. Karena itu biasanya di ajarkan pada anak-nak mereka mantra supaya mereka tidak terkena pengaruh jin yang ada di tempat tersebut. Yang nyata dapat kita lihat mengenai kemalik ini misalnya di Kadus Batu Tambun Desa Wakan. Kemalik ini berupa pohon besar yang di yakini oleh masyarakat sekitar di huni oleh banyak jin, bahkan oleh masyarakat sana di yakini sebagai tempat tinggalnya banyak jin, kemalik ini memiliki seorang pemangku yang menjaga tempat tersebut. Bukan hanya itu di bawah pohon besar tersebut di buatin semacam gubuk yang di yakini sebagai tempat istirahatnya mahluk gaib yang menghuni sekitar pohon tersebut. Sedangkan orang yang berani masuk dan membersihkan apa lagi memotong-motong ranting tersebut hanyalah pemangku kemalik tersebut. Kemalik ini juga bukan hanya berupa pohon, dan batu besar saja namun juga dapat berupa bangunan-bangunan tua, seperti sumur tua, pondasi masjid dan bangunan-bangunan lainnya.

Sedangkan ketobok berupa bangunan yang di buat masyarakat tidak berselang terlalu lama dan bangunannya dapat di perbaharui, baik di buat dengan beratapkan ilalang dan bertembokkan pager (bedek), serta ada juga yang temboknya terbuat dari batu bata dan di bangun seperti rumah kecil modern. Ketobok di buat karena di yakini oleh masyarakat sekitar bahwa di tempat tersebut pernah di tinggali oleh orang suci atau orang alim,

\section{e. Bebubus}

Bebubus merupakan salah satu kepercayaan masyarakat bahwa dengan cara tersebut mereka bisa sembuh dari penyakit yang di deritanya, di saat bebubus bisa meminta rizki yang banyak, di panjangkan umurnya dan lain sebagainya. Pada umumnya bebubus ini di lakukan pada hari senin yang di kenal dengan nama bubus senin, dan hari jum'at. Selain bubus yang di buat supaya yang memakainya bisa mendapatkan kebaikan, kesehatan, terhindar dari pengaruh gaib yang jahat sekaligus ada juga bubus yang di yakini dapat menarik hati peria atau wanita ketika di gunakan, namun pembuatan bubus semacam ini di lakukan secara sembunyi dan di rahasiakan. Adapun macam acara bebubus yang pertama terbuka dan di ketahui oleh umum, karena yang menggunakannya juga adalah masyarakat pada umumnya.

Bubus pada umumnya terbuat dari beras yang di tumbuk, dan di campur dengan bahan-bahan yang lainnya, pada saat pembuatannya juga tidak luput dari mantra- 
mantra, karena di sanalah inti dari pembuatannya. Karena itu bubus ini memiliki seorang pemangku, dan di warisi secara turun-temurun oleh keluarga pemangku tersebut. Bebubus ini sekaligus juga memiliki ikatan bubus, baik berupa kekerabatan maupun tempat tinggal. Dengan demikian walaupun berasal dari desa yang berbeda namun kadang-kadang pergi bebubus ke desa yang lain karena ikatan kekerabatan dengan pemangku bubus tersebut.

Masyarakat juga percaya bahwa pemangku bubus tersebut di kelilingi banyak mahluk halus, dan banyak juga orang yang bisa kena kejahatan mahluk halus yang di percayai sebagai penunggu bubus tersebut, misalnya mereka akan hilang kesadaran dan mengamuk, gejala pingsan atau bahkan sakit. Semuanya itu jika yang menyebabkan semuanya adalah mahluk halus yang ada pada bubus tersebut maka yang akan mengobatinya juga adalah pemilik bubus, atau paling tidak akan bisa sembuh setelah minum air bubus yang remas dan di usap-usap ke mukanya.

\section{f. Dukun/tabib}

Fungsi tabib sampai saat ini pada masyarakat pedesaan di kecamatan Jerowaru sama dengan fungsi seorang dokter, bahkan mereka lebih dahulu di tuju sebelum orang yang sakit tersebut di bawa ke dokter atau rumah sakit. Mereka bukan hanya bisa menyembuhkan satu penyakit, namun kadang-kadang menurut keyakinan masyarakat terdapat dukun yang memiliki kemampuan mantra pada penyakit yang berbeda. Cukup dengan komat kamit dan di sediakan mangkok berisi beras, lingkaran benang, cabe tandan, segelas air serta uang seadanya bisa satu atau dua ribu, setelah itu yang sakit tersebut akan di kasi minum air yang pernah di kasi mantera tadi, dan si dukun akan bilang penyakitnya sebentar lagi akan sembuh.

\section{g. Benda Pusaka dan Azimat}

Terkait dengan benda pusaka seperti keris, tumbak dan senjata lainnya yang dianggap memiliki kekuatan lain, akan banyak kita temukan di tempat lain. Karena itu dalam hal ini kami akan membataskan diri pada azimat. Azimat oelh masyarakat di percaya memiliki kekuatan untuk untuk menagkal tindakan-tindakan yang jelek dari orang lain baik secara pisik maupun psikis. Dalam hal pisik misalnya azimat ini di yakini dapat melindungi tubuh sang pemilik dari gangguan orang lain yang mau mencelakainya, tidak tembus besi, bahkan bisa menjadi kebal. Dalam hal psikis dapat menyebabkan si pemilik terhindar dari pengaruh sihir, atau kekuatankekuatan mahluk gaib yang jahat pada dirinya.

Azimat/bebadong ini bisa berupa kain, beberapa tulisan kertas maupun semacam minyak. Azimat atau bebadong yang terbuat dari kain biasanya berbentuk sabuk, hingga dalam keadaan yang berbahaya azimat tersebut dapat di gunakan sebagai sabuk. Begitu juga hanya dengan azimat berupa tulisan atau gambar alqur'an atau tulisan jawi, biasanya berukuran kecil dan dapat di masukkan dalam katong, sehingga oleh pemiliknya dapat di bawa kemanapun kecuali saat kencing dan membuang air besar, karena jika di bawa pada dua kegiatan tersebut di pecaya kekuatannya akan berkurang.

\section{h. Mantra-mantra Kekebalan Tubuh}

Seperti di jelaskan di atas bahwa bebadon atau azimat juga bertujuan untuk membuat tubuh si pemiliknya menjadi kebal dari pengaruh benda-benda tajam seperti keris, maupun tumbak jika di gunakan untuk membela diri di saat kepepet maupun ketika berhadapan dengan musuh. Selain itu kekebalan tubuh ini juga berupa mantra-mantra yang harus di kuasai oleh seseorang supaya tidak perlu lagi membawa bebadong atau azimat yang kadang-kadang lupa di bawa. Sedangkan mantra ini akan melekat pada individunya sebagai pelindung.

Mantra-mantra untuk dapat membuat tubuh menjadi kebal ini terdapat dua bentuk yaitu ada yang di namakan ilmu masak dan ilmu katak. Ilmu masak adalah ilmu kekebalan tubuh yang di ajarka oleh seseorang dengan cara biasa-biasa tanpa harus dengan persyaratan, bisa di ajarkan saat duduk nyantai dan sebagainya. Sedangkan ilmu masak di ajarkan oleh sang guru di tempat-tempat tertentu yang tersembunyi, serta pada bulan tertentu.

\section{i. Kemenyan}

Tujuan dari diadakannya kemenyan ini oleh masyarakat di yakini akan dapat menerangkan arwah nenek moyang yang telah meninggal du nia di alam sana, begitu juga nanti setelah orang yang menyalakan kemenyan itu meninggal dunia, mereka memiliki 
keyakinan bahwa akan mendapatkan ketenangan di alam ahirat nanti dengan melakukan kemenyan tersebut.

Kemenyan ini di lakukan pada tanggal 15 bulan ramadhan, karena masyarakat menganggap bahwa pada pertengahan bulan tersebut yang pada awal ramadhan arwah keluarganya yang telah meninggal dunia pulang ke rumahnya, namun pada pertengahan bulan tersebut di yakini bahwa arwah mereka akan kembali ke tempat asalnya, jadi dengan adanya kemenyan yang di nyalakan pada pada malam hari tersebut tidak lain adalah untuk menerangi perjalanan pulang arwah nenek moyangnya kea lam kubur.

Adapun pembuatan dari kemenyan ini, yaitu buah jarak yang di masukkan pada penusuk lidi yang jumlahnya tidak terbatas. Kemenyan ini lalu di nyalakan di sekeliling rumah dan di tempat-tempat yang dianggap penting. Pada intinya penempatan kemenyan ini sesuai dengan di mana seharusnya lampu ada, baik di dapur, ruang makan, depan teras, kamar mandi dan bahkan di jalan-jalan yang di lewati orang.

\section{j. Pelet, Senggeger, dan Sengasih-asih}

Pelet adalah mantra yang di gunakan seorang lakilaki atau perempuan untuk membuat pacarnya jatuh cinta sama penggunanya, biasanya pelet ini terkesan sebagai mantra yang kurang bagus di mata orang banyak karena di yakini dapat memaksakan cinta pada orang yang sebenarnya tidak mencintainya, dan yang paling parah lagi jika mereka dapat menikah, maka masyarakat yakin kalau dia dapat pasangannya tersebut dengan menggunakan pellet maka tidak akan berjalan lama, karena pada saat tertentu ketika pengaruh pellet tersebut tidak berpengaruh lagi maka perempuan atau laki-laki yang terkena pellet tersebut akan membenci suami atau istrinya, karena pada awalnya tidak di dasari rasa cinta yang murni. Karena itu penggunaan pelet bagi masyarakat adalah sesuatu yang kurang bagus.

Adapun cara penggunaan pellet ini bisa lewat rokok, uang, mata, sabut, atau makanan yang di berikan pada seorang gadis, dan disanalah di lakukan mantramantra. Sedangkan senggeger dan sengsih-asih hempir merupakan sesuatu yang sama dan dianggap bagus olah masyarakat, karena hanya akan menimbulkan kesenangan bagi orang lain melihat kita. Jika senggeger di gunakan untuk dapat di lihat menarik oleh pasangan kita, maka sengasih-asih di percaya dapat mempengaruhi orang banyak pada umumnya.

\section{Cara Generasi Tua Mewarisi Kepercayaan ini pada Generasi Muda.}

I Gede Wiranata (2002) dalam buku antropologi budayanya memberikan pemahaman bahwa terdapat tiga hal yang bisanya terjadi sehingga budaya tersebut dapat terus terlestarikan, yaitu melalui:

a. Proses Internalisasi

Proses internalisasi berlangsung sepanjang hidup individu sejak di lahirkan sampai hampir meninggal untuk mengolah segala perasaan, hasrat, nafsu dan emosi yang kemudian membentuk kepribadiannya, dan semua ini nyatanya sangat dipengaruhi berbagai stimulasi yang terdapat dalam lingkungan sosialnya, budayanya dan alam sekitarnya. Artinya bahwa individu dalam banyak hal tidak lepas dari kondisi sosial bidaya di mana mereka di besarkan dan bergaul dengan masyarakat, sehingga dengan sendirinya setiap individu akan terpengaruhi oleh keadaan tersebut.

b. Proses Sosialisasi

Proses sosialisasi adalah proses sosial di mana seorang individu menerima pengaruh, peranan, tindakan orang-orang di sekitarnya, seperti kakak, adik mertua, paman, pembantu dan lain-lain. Dimana proses sosialisasi ini akan sangat bervariasi karena di pengaruhi oleh struktur masyaraka, susunan kebudayaannya serta lingkungan sosial yang bersangkutan.

c. Proses Enkulturasi

Proses enkulturasi adalah proses sosial di mana individu belajar menyesuaikan diri dalam alam pikiran serta sikapnya terhadap adat, sistem norma, serta semua peraturan yang terdapat dalam lingkungan masyarakatnya. Berkaitan dengan proses-proses tersebut dalam kenyataannya di masyarakat tidak semua individu secara mulus melewati tahapan proses tersebut. Ada beberapa individu yang sukaar untuk menerima dan menyesuaikan diri dengan berbagai faktor yang di jumpainya dalam masyarakat. Hal ini dapat di akibatkan beberapa hal misalnya, tingkat pendidikan individu pada sistem sosial dan budaya dimana mereka tinggal, pengaruh budaya luar dan lain sebagainya yang kadang-kadang akan 
merusak, mempengaruhi atau terjadi akulturasi dengan budaya yang asli.

\section{SIMPULAN DAN SARAN}

Sutan Takdir Alisyahbana (Budiwanti: 2009) mengatakan bahwa adat-istiadat yang berlaku pada masyarakat berakar pada budaya yang dikembangkan oleh nenek moyang secara berkelanjutan bahkan tidak berkesudahan. Semua ini bisa terjadi pada masyarakat yang memiliki kolektivitas tinggi, dan memiliki salah satu ciri yaitu bidang pekerjaan yang homogen. Inilah salah satu faktor yang dapat menyebabkan kebudayaan masa lampau bisa di lestarikan, terutama dalam hal kepercayaan. Karen menurt ahli bahwa salah satu unsur budaya yang sangat sulit berubah yaitu kepercayaan, sedangkan budaya yang sifatnya materi cepat sekali terpengaruh oleh budaya luar, seperti model pakaian, perumahan, keprluan hidup sehari-hari dan lain sebagainya.

Pelestarian budaya masa lampau oleh masyarakat bisa terjadi melalui internalisasi, yaitu peruses penyatuan dengan lingkungan sosial dan budaya sekitar, Sosialisasi, berupa pengaruh orang yang ada di sekeliling kita, baik kakak, ayah ibu dan lain sebagainya, serta proses enkulturasi, yang berupa menyemaian budaya dalam kehidupan sehari-hari.

Moderenisasi telah menyebabkan kebudayaan luar sangat rentan mempengaruhi budaya asli masyarakat, yang kadang kelihatan lebih masuk akal, terutama dalam hal ini kebudayaan materi. Namun di balik layar televisi, internet, dan handpon, di sebagian masyarakat tidak akan bisa menghilangkan beberapa kebudayaan asli yang pernah ada, terutama dalam hal kepercayaan.

Begitu juga yang terjadi pada masyarakat pedesaan kecamatan Jerowaru Lombok Timur-NTB, walaupun masyarakatnya saat ini sudah bisa di katakana menuju masyarakat modern dengan menggunakan kebudayaan materi yang di lakukan orang pada umumnya, namun dalam hal kepercayaan mereka masih terikat oleh kepercayaan religuis-magis yang pernah menjadi kepercayaan nenek moyangnya.

Beberapa unsure kepercayaan religius-magis yang masih di lestarikan oleh masyarakat seperti bebubus, kepercayaan bahwa binatang seperti tikus, babi, ulat dan lain sebagainya memiliki kekuatan gaib, mereka juga meyakini kekuatan supranatural dari ketobok dan kemalik, mereka juga percaya pada mantra-mantra yang dapat mengakibatkan kekebalan tubuh, percaya pada pelet, senggeger serta sengasih-asih dan lain sebagainya.

\section{DAFTAR RUJUKAN}

Alisyahbana S. Takdir. 1988. Revolusi Masyarakat dan Kebudayaan di Indonesia. Dian Rakyat: Jakarta.

Budiwanti, Erni. 2002. Islam Sasak. LKIS, Yogyakarta.

Kahmad Dadang. 2006. Sosiologi Agama. Rosda Karya Bandung: Bandung

Kuntowijoyo. 2003. Metodologi Sejarah. Tiara Wacana Yogya: Yogyakarta.

Mulyana Agus \& Darmiasti. Historiografi di Indonesia: dari magis-religius hingga strukturis. Refika Aditama: Bandung.

Ritzer George \& Goodman J. Douglas. 2011. Teori Sosiologi. Kreasi Wacana: Bantul

Raho Bernard. 2007. Teori Sosiologi Modern. Prestasi Pustaka: Jakarta

Soekanto Soerjono. 1999. Sosiologi Suatu Pengantar. Rajagrafindo Persada: Jakarta.

Soedjatmoko, Ali Muhammad, dkk (ed). 1995. Historiografilndonesia: sebuah pengantar.

Gramedia Pustaka Utama: Jakarta.

Wiranata I Gede. 2002. Antropologi Budaya. Citra Aditya Bakti: Bandung. 